\title{
Penerapan Model Pembelajaran Kooperatif Tipe Note-Taking Pairs untuk Meningkatkan Hasil Belajar Pendidikan Agama Islam
}

\author{
Poniah \\ Sekolah Dasar Negeri 155 Pekanbaru, Indonesia \\ e-mail: Poniah@gmail.com
}

\begin{abstract}
This Classroom Action Research was conducted because the learning outcomes of Islamic Education in fourth grade students of SDN 155 Pekanbaru were still relatively low. To overcome this problem is to apply the cooperative learning type Note-Taking Pairs. The purpose of this study is to improve the learning outcomes of Islamic Education in grade four Students of SDN 155 Pekanbaru with the application of the cooperative learning model Note-Taking Pairs. The method of this research is Classroom Action Research (CAR) carried out in two cycles. Each cycle consists of two meetings and four stages, namely planning, implementation, observation, and reflection. This research was conducted in April 2018 in the second semester of the 2017/2018 school year. The subjects in this study were teachers and fourth grade students in the 2017-2018 school year with a total of 20 students divided into 11 men and 9 women. Data collection techniques used in this study were observation, testing, and documentation techniques. Based on the results of the study it can be concluded that before the treatment students who reach the completion standard were only 9 students or $45.00 \%$. In the first cycle it increased to 14 students or $70.00 \%$. In cycle II it increased again to reach 19 students or with a percentage of $95.00 \%$. So it can be concluded that by applying the cooperative learning model type Note-Taking Pairs can improve the learning outcomes of Islamic Education in fourth grade students of SDN 155 Pekanbaru.
\end{abstract}

Keywords: Cooperative Learning Model, Note-Taking Pairs, Learning Outcomes of Islamic Education.

\section{PENDAHULUAN}

Pelaksanaan pembelajaran di dalam kelas, setiap guru memerlukan kreativitas untuk menumbuhkembangkan daya imajinasi dan berpikir bagi peserta didiknya. Terkait dengan hal tersebut diperlukan uji coba secara terus-menerus dalam penerapan model pembelajaran di kelas. Pemilihan model pembelajaran yang tepat dapat menciptakan suasana pembelajaran yang aktif, kreatif, dan menyenangkan. Sehingga akan memudahkan siswa menerima dan memahami materi pembelajaran. Hal ini dipertegaskan oleh Roestiyah (2008:1) yang mengatakan dalam proses belajar mengajar, guru harus memiliki teknik atau metode, agar siswa dapat belajar secara efektif dan efisien, mengena pada tujuan yang diharapkan.

Model pembelajaran merupakan salah satu cara yang digunakan guru dalam penyampaikan materi pelajaran. Diharapkan penyampaian materi pelajaran tersebut, dapat diserap dan dipahami oleh siswa. Selain itu, salah satu tujuan pemilihan model pembelajaran yang tepat pada hakikatnya adalah untuk mencapai tujuan yang ingin dicapai dalam proses pembelajaran, diantaranya adalah tujuan Pendidikan Agama Islam. Tujuan mata pelajaran Pendidikan Agama Islam bagi siswa pada hakikatnya adalah untuk memperoleh hasil belajar yang memuaskan, yaitu hasil belajar yang mencapai Kriteria Ketuntasan Minimum (KKM) yang ditetapkan sekolah, yaitu 70 .

Hasil pengamatan pendahuluan yang dilakukan, dalam proses pembelajaran Pendidikan Agama Islam pada siswa kelas IV SDN 155 Pekanbaru ialah guru menjelaskan 
materi pelajaran dengan menggunakan metode ceramah, guru selalu memberikan umpan balik kepada siswa saat proses pembelajaran dengan cara bertanya kepada siswa, menggunakan media gambar yang berhubungan dengan materi pelajaran, dan di akhir pembelajaran melakukan evaluasi.

Kenyataannya hasil belajar siswa yang diperoleh belum optimal, gejala-gejala yang ditemukan di lapangan adalah sebagai berikut: 1) Nilai yang diperoleh siswa tidak mencapai Kriteria Ketuntasan Minimal (KKM). Dari 20 orang siswa, 55,00\% atau sekitar 11 siswa belum mencapai nilai KKM yang ditetapkan sekolah yakni 70. 2) Setiap kali diberi tugas rumah, rata-rata nilai siswa masih memperoleh nilai rendah, hal ini terlihat ketika diperiksa hanya 7 orang siswa atau 35\% yang dapat menjawab dengan benar.

Perlu pemilihan model pembelajaran yang tepat untuk mengajarkan materi pelajaran Pendidikan Agama Islam kepada siswa. Barkley (2012:203) menjelaskan bahwa model pembelajaran kooperatif tipe Note-Taking Pairs merupakan cara membantu siswa bagaimana mengerjakan tugas, memeriksa atau membuat catatan bersama pasangan mereka. Selain itu, model ini memberikan kesempatan siswa bekerja sama untuk mendapatkan informasi yang kurang atau terlewatkan dan mengoreksi catatan yang kurang teratur dan akurat agar hasil usaha bersama mereka ini menjadi lebih baik dari pada catatan-catatan individual.

Berdasarkan penjelasan yang telah dikemukakan, dengan model pembelajaran kooperatif tipe Note-Taking Pairs kualitas pembelajaran dapat ditingkatkan, sehingga perkembangan nilai atau hasil belajar siswa mengalami peningkatan. Kenyataan ini membuat peneliti tertarik untuk melakukan suatu penelitian tindakan sebagai upaya dalam melakukan perbaikan terhadap pembelajaran dengan judul "Penerapan Model Pembelajaran Kooperatif Tipe Note-Taking Pairs Untuk Meningkatkan Hasil Belajar Pendidikan Agama Islam Pada Siswa Kelas IV SDN 155 Pekanbaru".

Berdasarkan identifikasi masalah yang telah dipaparkan, maka dapat dirumuskan permasalahan dalam penelitian ini yaitu sebagai berikut: "Apakah dengan penerapan model pembelajaran kooperatif tipe Note-Taking Pairs dapat meningkatkan hasil belajar Pendidikan Agama Islam pada siswa kelas IV SDN 155 Pekanbaru?" Sesuai dengan latar belakang dan perumusan masalahnya, maka penelitian ini bertujuan untuk meningkatkan hasil belajar Pendidikan Agama Islam Pada Siswa Kelas IV SDN 155 Pekanbaru dengan penerapan model pembelajaran kooperatif tipe Note-Taking Pairs.

\section{METODOLOGI}

Penelitian tindakan kelas ini dilaksanakan di SDN 155 Pekanbaru, khususnya pada kelas IV. Mata pelajaran yang diteliti adalah mata pelajaran Pendidikan Agama Islam. Penelitian ini dilakukan pada bulan April 2018. Subjek dalam penelitian ini adalah guru dan siswa kelas IV tahun pelajaran 2017-2018 dengan jumlah siswa sebanyak 20 orang yang terbagi atas 11 orang laki-laki dan 9 orang perempuan. Penelitian ini merupakan penelitian tindakan kelas. Arikunto (2007:16) menjelaskan bahwa PTK merupakan proses perbaikan pembelajaran yang dilakukan oleh sejumlah partisipan (guru, siswa, dan peserta lainnya) di ruang kelas dalam rangka untuk memperbaiki proses pembelajaran di kelas. Tahapantahapan yang akan dilalui dalam penelitian tindakan kelas, yaitu: perencanaan/persiapan tindakan, pelaksanaan tindakan, observasi, refleksi. Teknik pengumpulan data yang digunakan adalah teknik observasi, tes, dan dokumentasi. Teknik analisis data terdiri dari:

\section{Aktivitas Guru dan Siswa}

Setelah data terkumpul melalui observasi, data tersebut diolah dengan menggunakan rumus persentase, yaitu sebagai berikut : 
Keterangan :

$$
P=\frac{F}{N} x 100 \%
$$

$\mathrm{P}=$ Angka Persentase aktivitas guru

$\mathrm{F} \quad=$ Frekuensi aktivitas guru

$\mathrm{N} \quad=$ Jumlah indikator

$100 \%=$ Bilangan tetap (Sudijono, 2004:43)

Tabel 1. Interval Kategori Aktivitas Guru dan Siswa

\begin{tabular}{ccc}
\hline No & Interval & Kategori \\
\hline 1 & $81-100 \%$ & Baik \\
2 & $61-80 \%$ & Cukup Baik \\
3 & $41-60 \%$ & Kurang Baik \\
4 & $0-40 \%$ & Tidak Baik \\
\hline Sumber: Arikunto & $(1998: 246)$ &
\end{tabular}

\section{Hasil Belajar}

Untuk menghitung hasil belajar siswa diperoleh melalui ketuntasan individu dan ketuntasan klasikal, untuk lebih jelas dapat dijabarkan sebagai berikut:

Ketuntasan Individu

Untuk menghitung hasil belajar secara individu dapat dihitung dengan menggunakan rumus sebagai berikut:

$$
S=\frac{R}{N} \times 100 \%
$$

Keterangan:

$$
\begin{array}{ll}
\mathrm{S} & =\text { Nilai yang diharapkan } \\
\mathrm{R} & =\text { Jumlah skor yang benar } \\
\mathrm{N} & =\text { Skor Maksimum (Trianto, 2008:171) }
\end{array}
$$

Ketuntasan Klasikal

Menurut Wardani (2006:1.19) secara klasikal siswa dikatakan tuntas, apabila 85\% dari jumlah siswa mencapai nilai KKM yang ditetapkan, yaitu 70. Sedangkan untuk menentukan ketuntasan secara klasikal rumus yang digunakan yaitu:

$$
K K=\frac{J T}{J S} x 100 \%
$$

Keterangan:

$$
\begin{array}{ll}
\text { KK } & =\text { Ketuntasan Klasikal } \\
\text { JT } & =\text { Jumlah Siswa yang Tuntas } \\
\text { JS } & =\text { Jumlah Siswa Keseluruhan (Trianto, 2008:171) }
\end{array}
$$

Adapun kriteria penilaian hasil belajar siswa dalam proses pembelajaran Pendidikan Agama Islam dapat dilihat pada tabel beriktu:

Tabel 2. Kategori Hasil Belajar

\begin{tabular}{rcc}
\hline No & Interval (\%) & Kategori \\
\hline 1. & $85-100$ & Amat Baik
\end{tabular}


2. $\quad 71-84 \quad$ Baik

3. $65-70 \quad$ Cukup

4. Kurang dari 65 Kurang

Sumber: Tim Pustaka Yustisia (2008: 362).

\section{HASIL DAN PEMBAHASAN}

\section{Hasil}

\section{Siklus I}

\section{Hasil Pengamatan Aktivitas Guru Siklus I}

Aktivitas guru dalam proses pembelajaran Pendidikan Agama Islam materi perilaku terpuji dengan model pembelajaran kooperatif tipe Note-Taking Pairs di siklus I dilaksanakan dan dinilai oleh pengamat berdasarkan lembar penilaian aktivitas guru (lampiran 6 dan 7). Hasil pengamatan aktivitas guru dengan penerapan model pembelajaran kooperatif tipe Note-Taking Pairs pada siklus I dapat dilihat pada tabel 3 berikut.

Tabel 3. Hasil Pengamatan Aktivitas Guru dengan Penerapan Model Pembelajaran Kooperatif Tipe NoteTaking Pairs Pada Siklus I

\begin{tabular}{lllll}
\hline No & Siklus & Pertemuan & Aktivitas Guru (\%) & Kategori \\
\hline 1 & I & I (Pertama) & $60,71 \%$ & Cukup Baik \\
& & II (Kedua) & $67,86 \%$ & Cukup Baik \\
\hline & Rata-rata & $64,29 \%$ & Cukup Baik \\
\hline
\end{tabular}

\section{Hasil Observasi Aktivitas Siswa Pada Siklus I}

Aktivitas siswa dalam proses pembelajaran Pendidikan Agama Islam materi perilaku terpuji dengan model pembelajaran kooperatif tipe Note-Taking Pairs di siklus I dilaksanakan dan dinilai oleh pengamat berdasarkan lembar aktivitas siswa (lampiran 10 dan 11). Hasil pengamatan aktivitas siswa dengan penerapan model pembelajaran kooperatif tipe NoteTaking Pairs pada siklus I dapat dilihat pada tabel 4berikut.

Tabel 4. Hasil Pengamatan Aktivitas Siswa dengan Penerapan Model Pembelajaran Kooperatif Tipe NoteTaking Pairs Pada Siklus I

\begin{tabular}{lllll}
\hline No & Siklus & Pertemuan & Aktivitas Siswa (\%) & Kategori \\
\hline 1 & I & I (Pertama) & $59,29 \%$ & Cukup Baik \\
& II (Kedua) & $67,86 \%$ & Cukup Baik \\
\hline & Rata-rata & $63,57 \%$ & Cukup Baik \\
\hline
\end{tabular}

Berdasarkan tabel 4 di atas, diketahui bahwa aktivitas siswa dengan penerapan model pembelajaran kooperatif tipe Note-Taking Pairs pada pertemuan 1 siklus I hanya mencapai persentase 59,29\% dengan kategori cukup baik. Pertemuan 2 siklus I hanya mencapai persentase $67,86 \%$ dengan kategori cukup baik. Secara keseluruhan rata-rata aktivitas siswa pada siklus I adalah 63,57\% dengan kategori cukup baik.

\section{Hasil Belajar Tes Siklus I}


Tabel 5. Hasil belajar siswa pada siswa kelas IV SDN 155

Pekanbaru pada siklus I dapat dilihat pada tabel 5 berikut

\begin{tabular}{cccc}
\hline \multirow{2}{*}{ No } & \multirow{2}{*}{ Interval (\%) } & $\mathbf{N}$ & Siklus I \\
\cline { 3 - 4 } & & 5 & $\mathbf{0}$ \\
\hline 1 & $85-100$ (Amat Baik) & 4 & $25,00 \%$ \\
2 & $71-84$ (Baik) & 5 & $20,00 \%$ \\
3 & $65-70$ (Cukup) & 6 & $25,00 \%$ \\
4 & $<65$ (Kurang) & 20 & $30,00 \%$ \\
\hline & Jumlah siswa & $100.00 \%$ \\
\hline
\end{tabular}

Berdasarkan tabel 5, diketahui bahwa persentase ketuntasan siswa pada siklus I mencapai persentase $70,00 \%$ atau 14 orang siswa yang tuntas. Persentase tidak tuntas sebesar 30,00\% atau 6 orang siswa yang tidak tuntas. Kemudian rata-rata hasil belajar siswa pada siklus I mencapai 72,50 dengan kategori baik. Walaupun hasil belajar siswa tergolong baik, namun belum mencapai indikator keberhasilan minimal 85\%. Untuk itu, perlu tindakan siklus berikutnya untuk meningkatan hasil belajar siswa tersebut, yaitu dengan penerapan model pembelajaran kooperatif tipe Note-Taking Pairs pada siklus II.

\section{Refleksi Siklus I}

\section{Kelemahan}

Berdasarkan hasil penelitian siklus I, diketahui bahwa kerhasilan siswa belum mencapai minimial $85 \%$. Adapun penyebabnya adalah: 1) materi yang disampaikan guru terlalu singkat dan kurang disertai contoh, 2) tingkat pengawasan dan bimbingan guru sangat kurang, sehingga belum terlihat kerjasama pasangan dalam membuat rangkuman poin utama pelajaran, dan 3) guru hanya meminta satu pasangan ketika mempresentasikan hasil rangkuman yang telah didiskusikan dan dengan membacanya dengan keras-keras. Akibatnya guru tidak mengetahui hasil kerja pasangan lain.

\section{Kekuatan}

Selain memiliki kelemahan, namun penelitian ini juga memiliki kekuatan, yaitu: : 1) guru telah menyampaikan tujuan pembelajaran dengan lengkap, 2) guru telah mengarahkan siswa berpasangan dengan teman sebangku, sehingga berjalan dengan tertib, 3) guru telah menetapkan waktu untuk kegiatan merangkum dan mengkoreksi, sehingga pelaksanannya berjalan dengan tertib.

\section{Alasan tindakan perbaikan}

Berdasarkan kekuatan di atas, pada siklus I hasil belajar siswa telah menunjukkan peningkatan dari sebelum tindakan. Pada sebelum tindakan siswa yang tuntas hanya 9 orang siswa atau 45,00\%. Sedangkan pada siklus I meningkat menjadi 14 orang siswa atau 70,00\%. Namun demikian, kerhasilan siswa belum mencapai minimial 85\%. Untuk pertemuan selanjutnya ketika menyampaikan materi pembelajaran sebaiknya disertai contoh, guru harus lebih meningkatkan pengawasan dan bimbingan, agar lebih terlihat kerjasama pasangan dalam membuat rangkuman poin utama pelajaran, dan guru sebaiknya tidak membiarkan setiap pasangan merangkum dan mengkoreksi melebihi waktu yang ditetapkan, serta memberikan kesempatan kepada seluruh siswa untuk mengajukan pertanyaan ketika proses kesimpulan, agar guru dapat mengetahui tingkat penguasaan siswa terhadap materi pelajaran.

\section{Siklus II}




\section{Hasil Pengamatan Aktivitas Guru Siklus II}

Aktivitas guru dalam proses pembelajaran Pendidikan Agama Islam materi perilaku terpuji dengan model pembelajaran kooperatif tipe Note-Taking Pairs di siklus II dilaksanakan dan dinilai oleh pengamat berdasarkan lembar penilaian aktivitas guru (lampiran 8 dan 9). Hasil pengamatan aktivitas guru dengan penerapan model pembelajaran kooperatif tipe Note-Taking Pairs pada siklus II dapat dilihat pada tabel 6 berikut.

Tabel 6. Hasil Pengamatan Aktivitas Guru dengan Penerapan Model Pembelajaran Kooperatif Tipe NoteTaking Pairs Pada Siklus II

\begin{tabular}{lllll}
\hline No & Siklus & Pertemuan & Aktivitas Guru (\%) & Kategori \\
\hline \multirow{2}{*}{ II } & I (Pertama) & $82,14 \%$ & Baik \\
& & II (Kedua) & $92,86 \%$ & Baik \\
\hline & Rata-rata & $87,50 \%$ & Baik \\
\hline
\end{tabular}

Berdasarkan tabel 6 di atas, dapat dijelaskan bahwa pertemuan I di siklus I aktivitas guru Berdasarkan tabel di atas, dapat dijelaskan bahwa pertemuan I di siklus II aktivitas guru dikategorikan baik dengan persentase $82,14 \%$, pada pertemuan 2 meningkat menjadi $92,86 \%$ dengan kategori baik. Secara keseluruhan aktivitas guru pada siklus II adalah $87,50 \%$ atau dengan kategori baik.

\section{Hasil Observasi Aktivitas Siswa Pada Siklus II}

Aktivitas siswa dalam proses pembelajaran Pendidikan Agama Islam materi perilaku terpuji dengan model pembelajaran kooperatif tipe Note-Taking Pairs di siklus II dilaksanakan dan dinilai oleh pengamat berdasarkan lembar aktivitas siswa. Hasil pengamatan aktivitas siswa pada siklus II dapat dilihat pada tabel 7 berikut.

Tabel 7. Hasil Pengamatan Aktivitas Siswa dengan Penerapan Model Pembelajaran Kooperatif Tipe NoteTaking Pairs Pada Siklus II

\begin{tabular}{lllll}
\hline No & Siklus & Pertemuan & Aktivitas Siswa (\%) & Kategori \\
\hline 1 & II & I (Pertama) & $79,29 \%$ & Baik \\
& & II (Kedua) & $90,00 \%$ & Baik \\
\hline & Rata-rata & $84,64 \%$ & Baik \\
\hline
\end{tabular}

Berdasarkan tabel 7 di atas, diketahui bahwa aktivitas siswa pada pertemuan 1 siklus II mencapai persentase 79,29\% dengan kategori baik. Pertemuan 2 siklus II meningkat menjadi 90,00\% dengan kategori baik. Secara keseluruhan rata-rata aktivitas siswa pada siklus II adalah 84,64\% dengan kategori baik.

\section{Hasil Belajar Tes Siklus II}

Hasil belajar siswa pada siswa kelas IV SDN 155 Pekanbaru pada siklus I dapat dilihat pada tabel 8 berikut.

Tabel 8. Hasil belajar siswa pada siswa kelas IV SDN 155 Pekanbaru pada siklus I

\begin{tabular}{cccc}
\hline \multirow{2}{*}{ No } & \multirow{2}{*}{ Interval (\%) } & \multicolumn{2}{c}{ Siklus I } \\
\cline { 3 - 4 } & & $\mathrm{N}$ & $\%$ \\
\hline 1 & $85-100$ (Amat Baik) & 8 & $40,00 \%$
\end{tabular}




\begin{tabular}{cccc}
2 & $71-84$ (Baik) & 4 & $20,00 \%$ \\
3 & $65-70$ (Cukup) & 7 & $35,00 \%$ \\
4 & $<65$ (Kurang) & 1 & $5,00 \%$ \\
\hline & Jumlah siswa & 20 & $100 \%$ \\
\hline
\end{tabular}

Berdasarkan tabel 8, diketahui bahwa persentase ketuntasan siswa pada siklus II mencapai persentase $95,00 \%$ atau 19 orang siswa yang tuntas. Persentase tidak tuntas sebesar 5,00\% atau 1 orang siswa yang tidak tuntas. Kemudian rata-rata hasil belajar siswa pada siklus II mencapai 81,50 dengan kategori baik. Artinya hasil belajar siswa telah mencapai indikator keberhasilan minimal $85 \%$, sehingga penerapan model pembelajaran kooperatif tipe Note-Taking Pairs hanya dilaksanakan sebanyak siklus II.

\section{Refleksi Siklus II}

Melihat hasil ulangan harian Pendidikan Agama Islam pada siklus II, maka dapat disimpulkan hasil belajar Pendidikan Agama Islam siswa kelas IV SDN 155 Pekanbaru mengalami peningkatan dari siklus I. Pada siklus I jumlah siswa yang tuntas hanya mencapai 14 orang siswa $(70,00 \%)$, terjadi peningkatan pada siklus II menjadi 19 orang siswa (95.00\%). Meningkatnya hasil belajar Pendidikan Agama Islam siswa kelas IV disebabkan penerapan model pembelajaran kooperatif tipe Note-Taking Pairs dapat mendorong aktivitas dan proses interaksi siswa, membiasakan siswa untuk bekerjasama, saling membantu dan merangsang siswa untuk berfikir secara aktif. Berdasarkan hasil tes pada siklus II ini, maka dapat dikatakan penelitian ini berhasil meningkatkan hasil belajar Pendidikan Agama Islam siswa kelas IV SDN 155 Pekanbaru.

\section{Pembahasan}

\section{Aktivitas Guru}

Aktivitas guru dengan penerapan model pembelajaran kooperatif tipe Note-Taking Pairs pada siklus I masih terdapat beberapa kekurangan, sedangkan pada siklus II aktiitas guru telah terlaksana sesuai dengan langkah-langkah yang telah dijelaskan pada teori dan meningkatkan hasil belajar siswa. Barkley (2012:205) menjelaskan bahwa model pembelajaran kooperatif tipe Note-Taking Pairs merupakan teknik yang memberikan kegiatan terstruktur pada siswa untuk mengumpulkan informasi, mengisi kekosongan, memeriksa, dan mengoreksi kesalahan, serta saling membantu satu sama lain untuk belajar menjadi pencatat yang lebih baik.

Diketahui bahwa pada siklus I aktivitas guru tergolong "Cukup Baik", dengan persentase $64,29 \%$ berada pada rentang 61-80\%. Pada siklus II meningkat menjadi $87,50 \%$ tergolong "Baik" berada pada rentang $81-100 \%$. Lebih jelas dapat dilihat pada tabel berikut:

Tabel 9. Rekapitulasi Aktivitas Guru dengan Penerapan Model Pembelajaran Kooperatif Tipe Note-Taking Pairs pada Siklus I, dan Siklus II

\begin{tabular}{llll}
\hline Siklus & Pertemuan & Persentase & Kategori \\
\hline I & Pertemuan I & $60,71 \%$ & Cukup Baik \\
\multicolumn{2}{l}{ Rata-Rata Siklus I } & $67,86 \%$ & Cukup Baik \\
\hline Siklus & Pertemuan & $64,29 \%$ & Cukup Baik \\
II & Pertemuan I & Persentase & Kategori \\
& Pertemuan II & $82,14 \%$ & Baik \\
& $92,86 \%$ & Baik
\end{tabular}


$\begin{array}{lll}\text { Rata-Rata Siklus II } \quad 87,50 \% & \text { Baik }\end{array}$

\section{Aktivitas Siswa}

Persentase aktivitas siswa pada siklus I (pertemuan 1 dan 2) adalah 62,23\% atau tergolong "Cukup Baik", karena $63,57 \%$ berada pada rentang $61-80 \%$. Pada siklus II persentase aktivitas siswa meningkat menjadi 84,64\% atau tergolong "Baik", karena 84,64\% berada pada rentang $81-100 \%$. Lebih jelas dapat dilihat pada tabel berikut ini:

\section{Tabel 10. Rekapitulasi Aktivitas Siswa dengan Penerapan Model Pembelajaran Kooperatif Tipe Note-Taking Pairs pada Siklus I, dan Siklus II}

\begin{tabular}{|c|c|c|c|}
\hline Siklus & Pertemuan & Persentase & Kategori \\
\hline \multirow[b]{2}{*}{ I } & Pertemuan I & $59,29 \%$ & Kurang Baik \\
\hline & Pertemuan II & $67,86 \%$ & Cukup Baik \\
\hline \multicolumn{2}{|c|}{ Rata-Rata Siklus I } & $63,57 \%$ & Cukup Baik \\
\hline Siklus & Pertemuan & Persentase & Kategori \\
\hline \multirow{2}{*}{ II } & Pertemuan I & $79,29 \%$ & Cukup Baik \\
\hline & Pertemuan II & $90,00 \%$ & Baik \\
\hline \multicolumn{2}{|c|}{ Rata-Rata Siklus II } & $84,64 \%$ & Baik \\
\hline
\end{tabular}

\section{Hasil Belajar}

Perbandingan hasil belajar siswa dari sebelum tindakan, Siklus I, dan Siklus II secara jelas dapat dilihat pada tabel berikut ini:

Tabel 11. Peningkatan Ketuntasan Hasil Belajar Siswa dari Sebelum Tindakan, Siklus I, dan Siklus II

\begin{tabular}{llll}
\hline \multicolumn{1}{c}{ Tes } & Jumlah Siswa & $\begin{array}{r}\text { Jumlah Siswa Yang } \\
\text { Tuntas }\end{array}$ & $\begin{array}{c}\text { Jumlah Siswa Yang } \\
\text { Tidak Tuntas }\end{array}$ \\
\hline Sebelum Tindakan & 20 & $9(45,00 \%)$ & $11(55,00 \%)$ \\
Siklus I & 20 & $14(70,00 \%)$ & $6(30,00 \%)$ \\
Siklus II & 20 & $19(95,00 \%)$ & $1(5,00 \%)$ \\
\hline
\end{tabular}

Melihat tabel 11 pada sebelum tindakan siswa yang tuntas secara keseluruhan adalah 9 orang siswa atau dengan persentase $45,00 \%$, siklus I siswa yang tuntas secara keseluruhan meningkat menjadi 14 orang siswa atau dengan persentase $70,00 \%$, dan pada siklus II siswa yang tuntas secara keseluruhan adalah 19 orang siswa atau dengan persentase 95,00\%.

Berdasarkan hasil tes, diketahui bahwa hsil belajar siswa mengalami peningkatan dari sebelum tindakan hingga siklus II. Peningkatan hasil belajar siswa disebabkan teknik pembelajaran kolaboratif Note-Taking Pairs telah terlaksana dengan baik. Barkley (2012:205) menjelaskan bahwa keunggulan menerapkan model pembelajaran kooperatif tipe NoteTaking Pairs adalah: 1) siswa lebih terbiasa dalam mengumpulkan informasi, 2) siswa lebih mengetahui kesalahan mereka sebagai proses perkembangan, 3) belajar saling membantu sama lain, 4) memberikan kemudahan dan membiasakan bagi siswa untuk mengerjakan tugas yang diberikan, dan 5) secara bertahap perkembangan nilai siswa atau hasil belajar siswa mengalami peningkatan.

\section{KESIMPULAN DAN SARAN}




\section{Kesimpulan}

Berdasarkan hasil penelitian yang telah dipaparkan di atas, maka dapat disimpulkan bahwa pada sebelum tindakan siswa yang tuntas hanya 9 orang siswa atau 45,00\%. Sedangkan pada siklus I meningkat menjadi 14 orang siswa atau 70,00\%. Pada siklus II meningkat lagi hingga mencapai 19 orang siswa atau dengan persentase 95,00\%. Dengan keberhasilan siswa tersebut, dapat disimpulkan bahwa dengan penerapan model pembelajaran kooperatif tipe Note-Taking Pairs dapat meningkatkan hasil belajar Pendidikan Agama Islam pada siswa kelas IV SDN 155 Pekanbaru.

Hasil penelitian diharapkan dapat berdampak secara praktis dan teoretis. Secara praktis yaitu: 1) kepada kepala sekolah hendaknya memfasilitasi guru dalam penerapan model pembelajaran kooperatif tipe Note-Taking Pairs karena pembelajaran ini dapat meningkatkan hasil belajar siswa. 2) Kepada guru Pendidikan Agama Islam disarankan dapat menjadikan model pembelajaran kooperatif tipe Note-Taking Pairs sebagai alternatif dalam kegiatan pembelajaran guru Pendidikan Agama Islam. 3) Bagi siswa diharapkan dampak dari penerapan model pembelajaran kooperatif tipe Note-Taking Pairs melekat untuk kegiatan belajar mengajar selanjutnya, dan lebih antusias serta aktif lagi dalam kegiatan belajar. Secara teoretis penelitian diharapkan memberikan kontribusi dalam pengembangan ilmu pengetahuan di SDN 155 Pekanbaru dan menjadi pelatihan bagi pihak sekolah dalam mengembangkan instrument pembelajaran (mengemas materi, metode, dan media) untuk meningkatkan hasil belajar yang lebih bermakna.

\section{Saran}

Berdasarkan pelaksanaan penelitian dan hasil penelitian yang telah diperoleh, maka peneliti memberikan saran yaitu bagi guru yang mengajar dikelas IV, khususnya untuk pelajaran Pendidikan agama islam penerapan model pembelajaran Kooperatif Tipe NoteTaking Pairs merupakan alternatif pembelajaran yang efektif digunakan guru untuk meningkatkan hasil belajar siswa dan selama proses pembelajaran, guru hendaknya menggunakan model mengajar yang bervariatif dan menarik perhatian siswa ssehingga siswa tidak merasa bosan.

\section{REFERENSI}

Ali \& Nurhayati. 2006. Pendidikan Agama Islam untuk SD Kelas III, Bandung: PT. Inti Prima Aksara.

Arikunto, S. 2007. Penelitian Tindakan Kelas, Jakarta: Rineka Cipta.

Arikunto, S. 1998. Prosedur Penelitian suatu Pendekatan Praktek, Jakarta: Rineka Cipta.

Aunurrahman. 2009. Belajar dan Pembelajaran, Bandung: Alfabeta,

Dimyati dan Mudjiono. 2002. Belajar dan Pembelajaran, Jakarta: Rineka Cipta.

Elizabert E. Barkley. 2012. Collaborative Learning Techniques (30 Metode Meraih Sukses

Bersama dalam Studi secara Efektif dan Menyenangkan, Bandung: Nusa Media.

Silbermen, Melvin L. 2009. Active Learning 101 Strategi Pembelajaran Aktif. Bandung: Insan Madani

Supriono. 2009. Cooperative Learning: Teori dan Aplikasi PAIKEM, Yogyakarta: Pustaka Pelajar. 